\title{
INTERTEXTUALITY OF FRENCH MOVIE TITLES
}

\author{
Vladislav E. Anisimov ${ }^{1}$, Ekatherina D. Kalinnikova ${ }^{2^{\star}}$ \\ ${ }^{1} \mathrm{PhD}$ student RUDN University, RUSSIA, anisimov_ve@rudn.university.ru \\ ${ }^{2}$ Master student RUDN University, RUSSIA, kate.dk01@gmail.com \\ ${ }^{*}$ Corresponding Author
}

\begin{abstract}
The intertextuality presents an integral part of the modern education in High school. Movie title is the important pragmatic element of the film text corresponding to the film plot, thematic focus and ideological and figurative content of the film. The aim of this paper is to analyse the mechanismes of intertextuality in French movie titles and to show their pragmatical impact to the target audience. The research material includes 50 titles of contemporary French movies and their intertextual characteristics. Being one of the important part of the film text, a film title represent a large material from the point of view of intertextuality. The intertextual connections present in the film discourse pragmatically significant elements, especially in film titles help the target audience correctly interpret the film storyline and its genre component. The results obtained from our analysis allow us to make generalized conclusion about cases of intertextuality of French film titles. All the intertextual connections present in French film titles are based on the precedent texts of the French film discourse inspired by literary works, biographies of famous personalities and significant French historical events and can be divided into the direct and indirect references. Direct references of French films movie titles appeal to a specific literary work, historical event or a famous person. Indirect references, in turn, are not directly connected with the precedent text, but they are generally identified by the film target audience. The intertextual references we have considered in French films movie titles help film authors with the implementation of the movie title main function: to attract as many representatives of the target audience as possible and contribute to a successful film box office. The results obtained in this research can be successfully used as examples of intertextuality in the process of teaching linguists as well as for translation teaching of French films movie titles into the native language of students.
\end{abstract}

Keywords: intertextuality, film discourse, French films, movie title, intertextual connection, education.

\section{INTRODUCTION}

Nowadays the phenomenon of cinema discourse are researched by a wide range of scholars. Our overview of different studies about cinema discourse shows an increased interest to its translation, adaptation and localization (Chaume 2004, Gorshkova 2014, Gambier 2002, Valentini 2011) and the theoretical foundations of the cinema discourse itself and its elements (Buckland 2000, Bubel 2006, Kozloff 2000). The aim of this paper is to analyse the mechanismes of intertextuality in French movie titles and to show their pragmatical impact to the target audience. Movie titles are vivid representative materials for the study from the point of view of intertextuality. As we mentioned previously, the movie title is an important pragmatic element of the film text that "should correspond to the plot, thematic focus and ideological and figurative content of the film, while remaining interesting and attractive to the audience" (Anissimov, Borisova Konson 2019, p. 435). The intertextual connections present in the film discourse and its pragmatically significant elements, including in the film title, contain a number of allusions that help the target audience correctly interpret the genre 
component of the film and its storyline. They also help the audience make a choice on behalf of viewing the given movie. The target audience actively participate in film's success. For Bubel, "the active audience implies that the audience is always an active participant and that media content is always open to interpretation" (Bubel 2006, p. 46). The correct interpretation of the intertextual allusions in a film helps the target audience choose the right film to view and contribute to its succesful box office. The study of intertextuality is also very important for language-orientated education in the field of teaching translation in high school.

\section{RESEARCH MATERIAL}

The research material includes 50 titles of contemporary French movies and their intertextual characteristics. Proceeding from the idea of intertextuality and the possibility of its applying beyond the literary discourse, including the cinema discourse, we believe that intertextual connection covered by our research widely contribute to the impelling to the film viewing as much as possible audience (Ivanova 2001, Fedorova 2015, Moliterno 2010, Serrano 2005).

\section{THEORETICAL APPROACHES OF INTERTEXTUALITY AND ITS ROLE IN FILM DISCOURSE}

In 1966 French linguist J. Kristeva coined the term "intertextuality" by focusing on the concept of "dialogism", proposed by the Russian scientist M. M. Bakhtin. Intertextuality, according to her, is "a mosaic of quotations; any text is the absorption and transformation of another" (Kristeva, 1986, p. 37).

Based on Rolan Barthes's idea that we any text can be considered as intertext (Barthes 1989, p.415), we can concede the various allusions and references presented in their movie titles as intertextual components. If a recipient correctly interprets a reference to a certain precedent text or event, he immediately begins to associate the film production with this allusion, e.g. the screen version of a literary work will be principally associated by the target audience with a book, and the film-biography - with a specific historical person.

The lack of understanding of the intertextual relations between the film text and its pretext can lead to the wrong understanding of the whole film (Ivanova 2001, p. 5). The important role of the movie title is to convey the key idea and messages of the film director to the recipient. Due to the large pragmatic orientation of these film text elements, their ability to be understood and correctly interpreted by the film target audience plays a special role.

Initially, the phenomenon of intertextuality was developed and used for the analysis of literary discourse works. Today, however, research on this phenomenon is conducted on the basis of others types of discourse (scientific, political, news, advertising), including the film discourse (Ivanova 2001, Fedorova 2015, Moliterno 2010, Serrano 2005). This proliferation of intertextuality into different types of discourse gives rise to new research paradigms. Intertextual connections in film discourse have been considered by researchers from various points of view: the film adaptation and its intertextual connections with a literary work or comics (Moliterno 2010, Serrano 2005), allusions to various television and cinematic shooting techniques (Rachel 2011).

As an intertextualized text, the film text and its elements contain various kinds of intertextual references and allusions, appealing to the precedent texts of the film. It is possible to consider the film discourse and the film itself as a source of intertextual references as well. At that case, the film presents the so-called "intertextual base" for other films. A typical example of this type of reference between several films is multiepisode films (dilogies, trilogies), that can be considered as a single semiotic space.

\section{MOVIE TITLE AS AN INTEGRAL PART OF THE FUNCTIONAL AND PRAGMATIC ELEMENTS OF THE FILM TEXT}

The film text embraces a number of important viewer-faced elements. In this paper we use the authors' definition of the functional and pragmatic elements of the film text, which are pragmatically-oriented graphic (visual) elements of the film text that precede the film box office debut, directly affects its success by impelling to the film viewing as much as possible audience. The main functional and pragmatic unit of the movie text is the movie title. The functional and pragmatic elements of the film text have a special task in terms of implementing the intertextual connections they entailed. Being placed in the socio-cultural space long before the release of the film itself, they are able and even should be aimed at transmitting to the potential audience information about the allusions contained in them to precedent texts, events or other films. 
The main functional and pragmatic unit of the movie text is the movie title. The movie title is the first element of the movie discourse that a potential viewer encounters while trying to choose a movie for a viewing in cinema or online. It entitles the work and responds the viewer (in whole or in part) to the question about the content of the film (Pungă, Badea, 2018 p. 56). The movie title also affects the audience's perception of the film, causing the audience to have certain associations and emotions that are most often necessary for the authors of the film. Pungă and Badea also emphasize the influence of the movie title on the public and the motivation of potential viewers to view the film itself (Pungă, Badea 2018, p. 57).

According to I.P. Fedorova, the dominant role of the film title and its genre affiliation in the manifestation of intertextual connections of the film at the pre-screening stage (Fedorova 2015, p. 321). As an integral part of the text space, the name of each text provides intertextual connections among all the text components, as well as the connection between the text under consideration and other texts (Alexandrova Krasina Rybinok 2019, p. 26).

\section{RESULTS OF THE RESEARCH}

Our quantitative calculation revealed that intertextual allusions and references are mostly contained in movie titles (59\%), than in other functional and pragmatic elements of the film text - synopses (31\%) and slogans $(10 \%)$ of movies.

The most common precedent texts and events in French cinema discourse are literary works, historical events of world and national significance, and famous personalities biographies (Anisimov 2020, p. 365).

The intertextual component of the film title in interaction with precedent phenomena is manifested in making direct reference to specific literary works, historical events, outstanding personalities and their biographies, as well as other film productions of a similar genre. There are, however, cases of performing a whole complex of allusions by movie title, e.g. the title of the French movie Notre Dame (2019) contains an allusion to Victor Hugo's novel Notre Dame de Paris ('The Hunchback of Notre-Dame') and can also serve as a reference to the musical of the same name or even the Cathedral itself - one of the symbols of Paris.

The allusion multiplicity in the movie title can also be manifested by a number of references, e.g. the movie title of 1492: Christophe Columbus ('1492: Conquest of Paradise', 1992) contains the precedent name of the navigator Christopher Columbus and mentions the year of his discovery of the Americas.

As we mentioned above, intertextual connections in movie title can also be expressed in appeals to various significant for a potential audience pretexts: literary and cinematic characters, historical events, etc. According to our research, it is possible to divide the references present in the titles of films into direct and indirect references. Direct references appeal to a particular case text, event, or character. Indirect references create abstract allusions to pretexts.

A direct reference in the French films titles can be an allusion to a precedent event or to an important person for national or world history and culture. Thus, the above movie titles ('Notre Dame' (2019), '1492 : Christophe Colomb' (1992), as well as most titles of historical and biographical films (De Gaulle (2020); Jeanne ('Joan of Arc', 2019); Dalida (2016); Coco avant Chanel ('Coco Before Chanel', 2008), etc.), along with the titles of screen adaptations of literary works (Je voudrais que quelqu'un m'attende quelque part ('I Wish Someone Were Waiting For Me Somewhere', 2020); Les trois mousquetaires ('The Three Musketeers', 2011); Les rivières pourpres ('The Crimson Rivers', 2000), etc.) can be considered as direct references to the film's pretexts. Intertextual references connected with a screen adaptation demand from the film authors the knowledge of the values of the viewers. This idea is also expressed in Leontovich's work: "The screen or stage adaptation of a literary work has to be adapted to the knowledge base, tastes and value system of the target audience" (Leontovich 2019, p. 405).

Indirect references are oblique allusions that do not contain a direct reference to the precedent text. Due to the pragmatically-oriented component of the movie title, such references are only partially veiled and in most cases are easily identified by the audience, e.g. the title of the film 'D'après une histoire vraie' (2017, literal translation - "Based on real events"), which does not directly indicate the person whose biography is this film is based on. In addition, such a movie title has a great pragmatic orientation by attracted documentary films fans, if they do not take into account others film text elements.

Indirect references in French movie titles can also be made by appealing to a precedent work. Thus, the title of the movie 'Nicky Larson et le Parfum de Cupidon' (2019, literary translation "Nikki Larson and the Perfume of Cupid") can structurally serve as a reference to a series of books (and later film productions) about Harry Potter by repeating the titles of books (which gave names to movies), where the first place, including in the French translation of this book by J. K. Rowling, is the name of the main character of the work, following by a 
precedent detail of the storyline (Harry Potter and the Chamber of Secrets; Harry Potter and the Prisoner of Azkaban; Harry Potter and the Goblet of Fire, etc.).

\section{CONCLUSION}

The results of the research brings us to the following conclusion: the analyzed cases of intertextuality in the movie titles of French films represent the deliberate application of allusions to literary works, historical events and biographies of famous personalities provided by the film director and his team. These methods help the film authors with the implementation of the movie title main function: to attract as many representatives of the target audience of the film as possible to view it in order to ensure its success at the box office. The intertextual connections we have considered in French films movie titles can be divided into direct and indirect references. Direct references in movie titles appeal to a specific literary work, historical event, or a famous person. Indirect references do not directly mention the case text. However, they are quickly identified by the target audience. The results obtained in this research can be successfully used as examples of intertextuality in the process of teaching linguists as well as for translation teaching of French films movie titles into the native language of students.

\section{FOUNDING/AKNOWLEGMENT}

The publication has been prepared with the support of the «RUDN University Program 5-100» (project number 056111-0-000). Authors 1 and 2 all contributed equally and should be considered co-first authors.

\section{REFERENCE LIST}

Gambier, Y. (2002). Circulez, il y a à voir... aspects multiformes de «l'adaptation» cinématographique // Identité, altérité, équivalence? La traduction comme relation : Actes du Colloque International tenu à I'ESIT les 24, 25 et 26 mai 2000. Paris : Caen: Lettres modernes Minard, p. 339-358.

Chaume, F. (2004a) Cine y traducción / Frederic Chaume. Madrid : Cátedra. 336 p.

Valentini, C. (2011). La traduction des références culturelles dans le doublage pour le cinéma et la télévision: résultats d'une analyse empirique. Traduction et médias audiovisuels. Paris: Septentrion, pp. 93-109.

Anisimov, V.Eu.(2020). Intertextuality of the Small Texts of the French Film Discourse. RUDN Journal of Language Studies, Semiotics and Semantics, 11(2), pp. 357-367. doi: 10.22363/2313-2299-2020-112-357-367.

Leontovich, O. (2019). "A Sensible Image of the Infinite": Intersemiotic Translation of Russian Classics for Foreign Audiences. Russian Journal of Linguistics, 23 (2), pp. 399—414. doi: 10.22363/231291822019-23-2-399-414.

Anissimov, V. Eu., Borissova, A. S., Konson, G. R. (2019). Linguocultural Localization of Movie Titles. Russian Journal of Linguistics, 23 (2), 435—459. doi: 10.22363/2312-9182-2019-232-pp. 435-459.

Kristeva, J. (1986) "Word, Dialog and Novel", ed. Toril Moi, The Kristeva Reader, New York: Columbia University Press, pp. 34-61.

Fedorova, I.P. (2015). Intertextuality in film dialogue. Vestnik Nizhegorodskogo universiteta im. N.I. Lobachevskogo. pp. 320-324. (In Russ.).

Moliterno, G. (2010). Cinematic Intertextuality and Comic Allusion in Giorgio Mangiamele's Ninety Nine Per Cent. Screening the past. URL: http://www.screeningthepast.com/2015/01/ cinematic-intertextualityand-comic-allusion-in-giorgio-mangiamele\%E2\%80\%99s\%C2\% A0ninety-nine-per-cent/ .

Serrano, D.H. (2005). Intertextuality and Fidelity in Batman Movie Adaptations. URL: http://www.batman-on-film.com.

Rachel, J. (2011). Media Intertextuality. URL: www.slideshare.net.

Alexandrova, O.I., Krasina, E.A. \& Rybinok, E.S. (2019). Precedent phenomena of a film text: feature film title in the terms of translation. Philological Sciences. Scientific Essays of Higher Education, 5, pp. 22-33. Doi: 10.20339/PhS.5-19.022. (In Russ.). 
Gorshkova, V.E. et al. (2014). In V.E. Gorshkova (Ed.), Film dialogue. Image-sense. Translation. Irkutsk: MGLU EALI. (In Russ.). 367 p.

Bubel, C. (2006) The linguistic construction of character relations in TV drama : Doing friendship in Sex and the City : Dissertation zur Erlangung des akademischen Grades eines Doktors der Philosophie der Philosophischen Fakultäten der Universität des Saarlandes / Bubel Claudia. - Saarbrücken : Universitaet des Saarlande. - 294 p.

Kozloff, S. (2000) Overhearing Film Dialogue. Berkeley ; Los Angeles ; London : University of California Press. $323 \mathrm{p}$.

Buckland, W. (2000). The Cognitive Semiotics of Film. Cambridge: Cambridge University Press. 188 p.

Pungă L., Badea G. (2018) "Lost in translation". On some English movie titles and posters and their French and Romanian equivalents // SKASE Journal of Translation and Interpretation 11(1): pp. 55-68. 